\title{
Asset confiscation in Europe \\ - past, present, and future challenges
}

\author{
Professor dr. Johan Boucht, University of Oslo
}

\begin{abstract}
Purpose of this paper: The purpose of this paper is to paint a general picture of the asset confiscation regimes utilised in Europe, and to outline potential challenges, practical and related to issues of principle, associated with the current development with regard to the confiscation of the proceeds of crime and criminals' proceeds.
\end{abstract}

Design/methodology/approach: The paper endeavours to analyse the current various steps of the confiscation process, and the various approaches to the confiscation of proceeds of crime and criminals' proceeds from a holistic perspective. The findings of the paper are based on a literature review along with a legal analysis of the existent legal frameworks.

Findings: It is suggested that the efficiency of asset confiscation should be looked at from a holistic perspective involving the entire confiscation process, and not only focus on the confiscation powers awarded the courts. Challenges relating to efficiency exist along the entire process, from the stage of financial investigations to the enforcement stage. Some of the methods used for confiscating criminal proceeds are becoming very far-reaching and raise concerns related to basic principles of criminal law and criminal procedural law.

Research limitations/implications (if applicable): This paper is not based on empirical research relating to, for example, the efficiency of confiscation. More empirical research would, however, be welcome in this field.

Practical implications: The paper suggests that the efficiency of asset confiscation is contingent on the entire confiscation chain functioning efficiently. Before new and more repressive measures are introduced, the existing legal framework should be fully deployed and the concrete needs for new tools clearly delineated.

What is original/value of paper: It analyses the entire confiscation chain rather than merely looking at a particular confiscation scheme.

\section{Introductory remarks}

It is a basic point of departure in criminal justice policy in most countries that no perpetrator should profit from his crime. The moral imperative that no one should benefit from crime is generally strong. Economically motivated crime, such as corruption, serious fraud, drug and people trafficking and so on, have adverse effects on many parts of society, and the illicit profits generated through these activities may be considerable. Not only may criminal wealth be morally reproachable, but it may also undermine financial structures of our society. It is therefore important to have in place mechanisms that facili- 
tate effective confiscation of illicit profits generated by unlawful conduct, in some cases even where the individual has not been convicted of a criminal offence.

These mechanisms should be constructed in a way that facilitates effective implementation and achievement of their objectives. However, when implementing confiscation schemes, which may have considerable adverse effects on the individuals subjected to them, it is crucial that also the rights of these individuals are safeguarded in an effective manner.

During the past two decades or so, the confiscation of criminal proceeds has been devoted considerable political attention, and ever broader confiscation schemes have been viewed in many countries as necessary means of combating acquisitive crime, particularly organized crime and serious economic crime. 'This development has been supplemented by a considerable expansion of available anti-money laundering measures that seek to prevent offenders from concealing the predicate offences from which the proceeds derive, and to prevent the offenders from benefiting from their proceeds. ${ }^{2}$

In Europe the EU has been an important player in developing confiscation law for the purpose of making confiscation within the EU more effective. ${ }^{3}$ The EU has been particularly active in the field of substantive approximation of confiscation regimes, and for creating a procedural infrastructure that intends to enhance horizontal cooperation between the EU member states, for example by facilitating mutual recognition of freezing and confiscation orders. ${ }^{4}$

\section{The broader picture}

The term confiscation refers to a long process potentially resulting in the deprival of the confiscation subject's ill-gotten gains. This chain can be said to involve five phases. In order for the confiscation regime to be effective the whole chain must function efficiently.

A crucial first part is the investigative phase. The financial investigation purports to identify and track criminal assets for the purpose of subsequent confiscation, but also for the purpose of investigating a particular offence. In the words of the FATF, a financial investigation is an enquiry into the financial affairs related to a criminal activity, with a view to:

1) identifying the extent of criminal networks and/or the scale of criminality;

2) identifying and tracing the proceeds of crime, terrorist funds or any other assets that are, or may become, subject to confiscation; and

\footnotetext{
' For a historical overview of the development of confiscation laws, see for example M Fernandez-Bertier, 'The History of Confiscation Laws: From the Book of Exodus to the War on White-Collar Crime', in K Ligeti and M Simonato (ed.), Chasing Criminal Money. Challenges and Perspectives on Asset Recovery in the EU (Hart Publishing, 2017), 5375 .

${ }^{2}$ See e.g. the EU's fourth money laundering Directive (2015/849). See also the Commission's proposal for a directive on countering money laundering by criminal law which includes inter alia minimum rules concerning the definition of criminal offences. See COM(2016) 826 final. See Regulation (EU) 2018/1805 of the European Parliament and the Council of 14 November 2018 on the mutual recognition of freezing orders and confiscation orders. The proposal has been criticised (see eucrim 2/2017, p. 66-67).

${ }^{3}$ See e.g. M Simonato, 'Confiscation and fundamental rights across criminal and non-criminal domains', ERA Forum (2017), p. 367-368.

${ }^{4}$ See e.g. J Boucht, The Limits of Asset Confiscation. On the Legitimacy of Extended Appropriation of Criminal Proceeds (Hart Publishing, 2017), p. 30-33.
} 
3) developing evidence which can be used in criminal proceedings (such as money laundering, corruption or fraud).

The efficacy of asset confiscation regimes is therefore contingent on the prior financial investigations being thoroughly and efficiently conducted.

Within the EU, cooperation in financial investigations often involves the exchange of financial intelligence as a first stage to the gathering of actual evidence. An important channel for information exchange within the EU is through the network of Asset Recovery Offices (AROs) established in member states. ${ }^{6}$ The purpose of establishing AROs was to create national authorities between which information would flow freely and swiftly. There are currently 28 AROs in place. Another way of obtaining information is through the Camden Asset Recovery Interagency Network (CARIN), a worldwide informal network of expert practitioners working with asset confiscation. ${ }^{7}$ CARIN currently has 53 registered member jurisdictions, including $27 \mathrm{EU}$ Member States and nine international organisations (such as Eurojust, the International Criminal Court, UNODC, and Interpol). A third available path for obtaining information (in the $\mathbf{E U}$ ) is by way of establishing a Joint Investigation Team (JIT) pursuant to Art. 13 of the EU's Convention on Mutual Assistance in Criminal Matters of $2000 .{ }^{8}$

Having traced and identified the assets in question, there is often a need to protect them from being dissipated, or even destroyed, by the suspect(s). The second phase is therefore closely connected with the former, and involves the temporary freezing or seizure of suspected assets once they are identified. ${ }^{9}$ Freezing refers, in the words of the Warsaw convention, ${ }^{10}$ to the temporary prohibition of the transfer, destruction, conversion, disposition or movement of property, or the temporary assuming of custody or control of property on the basis of an order issued by a court or other competent authority." This may involve the freezing of assets in bank accounts of the seizure of property, such as cars, livestock or buildings.

In order to make the freezing process in the EU easier, the 2003 Framework decision on the execution in the EU of orders freezing property or evidence, stipulates that the principle of mutual recognition also applies to pre-trial freezing orders issued for the purpose of securing subsequent confiscation of property. ${ }^{12}$ The idea is that a member state shall recognise and execute in its territory a freezing order issued by a judicial authority of an-

\footnotetext{
${ }^{5}$ International Standards on Combating Money Laundering and the Financing of Terrorism \& Proliferation, The FATF Recommendations (February 2012; printed in February 2013), p. 97.

${ }^{6}$ See the Framework Decision 2007/845/JHA (6.12.2007) concerning cooperation between AROs of member states in the field of tracing and identifying proceeds from, or other property related to, crime. See also Council Decision (17.10.2000) concerning arrangements for cooperation between financial investigation units of the member states in respect of exchanging information (2000/642/JHA).

${ }^{7}$ The aim when CARIN was founded in 2004 was to establish an informal network of practitioners and experts for the purpose of improving mutual knowledge on methodologies and techniques in the area of cross-border identification, freezing, seizure and confiscation of the proceeds of crime (see CARIN Manual (2012), p. 4). The permanent secretariat is based in the Europol headquarters at the Hague and the organization is governed by a Steering Committee of nine members and a rotating Presidency

${ }^{8}$ The Convention on Mutual Assistance in Criminal Matters between the Member States of the European Union (2000/C 197/01). On the setting up of JITs, see e.g. Claudia Gualtieri, Joint Investigation Teams, ERA Forum (2007), p. 233-238.

${ }^{9}$ At EU level, freezing orders are regulated by the 2014 confiscation directive. According to Art. 7, Member States shall take the necessary measures to enable the freezing of property with a view to possible subsequent confiscation.

${ }^{10}$ Art. 1 of the Council of Europe Convention on Laundering, Search, Seizure and Confiscation of the Proceeds from Crime and on the Financing of Terrorism, Warsaw 16.5.2005

"Art. 1 of the Council of Europe Convention on Laundering, Search, Seizure and Confiscation of the Proceeds from Crime and on the Financing of Terrorism, Warsaw 16.5.2005.

${ }^{12} 2003 / 577 /$ JHA.
} 
other member state in the framework of criminal proceedings without further formality being required.

The Commission in December 2016 presented a proposal for a Regulation on the mutual recognition of freezing and confiscation orders, which aims to bring the EU's procedural confiscation regime a step further. ${ }^{13}$ This is the first time that a Regulation in the field of asset confiscation has been proposed and a national implementation process will therefore no longer be required. The objective is to make freezing in Europe faster and more efficient, by, for example, setting short deadlines for executing freezing orders and establishing a standard procedure for applying for them. ${ }^{14}$ To the degree that member states are bound by this Regulation, it will replace the 2003 Framework Decision with a view to the subsequent confiscation of property.

The freezing and seizure phase may involve the need to manage the assets thus seized or frozen. ${ }^{15}$ For example, the EU's Confiscation Directive (2014/42/EU) specifically includes provisions on management of seized property. The need for proper management of seized property that takes the assets into custody, manages them to ensure that the value is preserved during the often lengthy process to confiscate, and even possibly increases their profitability within the legal framework, is also internationally recognised. ${ }^{16}$

Asset management is important both from the perspective of the state and of the respondent. It is normally in the state's interest that the value of the seized assets is preserved, so that the state upon realization of the assets will be able to secure the claims in support of which they have been seized. If the value has decreased due to mismanagement, the state is less likely to cover its claims from the seized property. From the perspective of the person whose property is seized or confiscated, there is a reasonable expectation (in light of Art. 1 ECHR-P1) that the state adequately maintains the property so that no unreasonable decline in its value occurs. ${ }^{17}$ This is particularly important in cases where the criminal charges are finally dropped and the property is returned to the owner. Arguably, whether or not the authorities have arranged for the seized property to be properly managed may in fact be ascribed relevance in determining whether or not an excessive burden has been placed on the individual under Art. 1 ECHR-P1. Where

\footnotetext{
${ }^{13} \operatorname{COM}(2016) 819$ final. The proposal has been criticised, however, for not safeguarding the rights of third parties (see Eucrim 2/2017, p. 73).

"See Regulation (EU) 2018/1805 of the European Parliament and the Council of 14 November 2018 on the mutual recognition of freezing orders and confiscation orders.

${ }^{15}$ According to Art. 10 of the Directive, member states shall take the necessary measures, for example by establishing centralised offices or equivalent mechanisms, to ensure the adequate management of property frozen with a view to possible subsequent confiscation. This may involve granting powers to realise frozen property at least where it is liable to decline in value or become uneconomical to maintain. In some countries, such as Czech Republic, the state has a right to pre-conviction sake of frozen assets.

${ }^{16}$ See e.g. Art. 31 of the Proposal for Regulation on Mutual Recognition of Confiscation and Freezing ORders COM 2016 (819) final (general approach). See also G8 Best Practices for the Administration of Seized Assets, 27.5.2005, p. 1 and Art. 31(3) in the UN Convention Against Corruption (2000) which stipulates that '[e]ach State Party shall adopt, in accordance with its domestic law, such legislative and other measures as may be necessary to regulate the administration by the competent authorities of frozen, seized or confiscated property covered in paragraphs 1 and 2 of this article.' Also Art. 6 of the Council of Europe Convention on Laundering, Search, Seizure and Confiscation of the Proceeds from Crime and on the Financing of Terrorism (2005) contains a similar requirement.

${ }^{17}$ An asset which has been seized should be preserved in the same condition it was at the time of seizure. Therefore, seized assets should be appraised in order to establish the market value, appropriately at the date of seizure. As regards management of businesses, an equity valuation of the business should be undertaken before any restraint or seizure is requested to accurately determine its debt load and equity (see Jean-Pierre Brun, Asset Recovery Handbook (World Bank, 2011), p. 97).
} 
mismanagement of assets has resulted in (considerable) economic losses for a subject subsequently acquitted, the state may be liable to compensation. ${ }^{18}$

The third phase of the confiscation chain will be for a court to order the identified, and possibly frozen, assets to be confiscated. I will return to this aspect in section 3.

The fourth phase involves the execution, or enforcement, of the confiscation order. This phase involves collecting the assets that have been ordered confiscated, unless they are already frozen or seized and thereby in the possession of the state. The enforcement phase would seem to be an Achilles' heel to the efficiency of confiscation in some jurisdictions. For example, in the UK there are apparently at the moment nearly 2 Billion GBP in unsatisfied criminal confiscation orders, and in Norway, according to statistics from 2013-17, only some $31 \%$ of decided confiscation orders are in fact also paid.

According to the EU's 2006 Framework Decision on the mutual recognition of confiscation orders, the principle of mutual recognition should apply also to confiscation orders. ${ }^{19}$ The framework decision establishes the rules under which a member state should recognise and execute in its territory a confiscation order issued by a court competent in criminal matters in another member state. As mentioned earlier, the Regulation (2018/1805) on the mutual recognition of freezing and confiscation orders covers both the freezing process and the mutual recognition of confiscation orders. ${ }^{20}$ To the degree that member states are bound by this Regulation, it will replace the 2006 Framework Decision.

As stated in Art. 10 of the EU's confiscation Directive (2014/42/EU), this stage may also involve management of assets. Although the state may wish to sell of the property as soon as possible, there may for various reasons be a need to hold on to the property for some time. For example, where the property that has been ordered confiscated consists of entire businesses, for example a hotel, a factory or a port, this will often involve the appointment of a receiver whose task it is to oversee the running of the business until its realisation. For example, according to s. 50-51 of the English Proceeds of Crime Act 2002 (POCA 2002), the court may appoint a receiver in respect of realisable property where the confiscation order has not been met. Such a receiver has power to take possession of the property, to manage or otherwise deal with the property and to realise the property, in such manner as the court may specify.

The fifth and final phase concerns the execution of and the disposal of the confiscated assets. There are various ways in which the state deals with confiscated property, and this is also affected by whether the state's confiscation schemes facilitate value based or property based confiscation, or both. For example, when the ownership of real-estate is transferred to the state, the property may often be sold. Other property may also be sold, or even destructed. The means thus obtained may then be transferred into the state's budget where they are mixed with other disposable means without necessarily being earmarked

\footnotetext{
${ }^{18}$ There is no given right that loss alleged to have been suffered due to an impoundment of property gives rise to compensation (see e.g. Adamczyk v. Poland, No. 28551/04 (ECtHR, 7.11.2006). As the ECtHR has noted on several occasions, any seizure or confiscation will entail damage, but the actual damage sustained should not be more extensive than that which is inevitable (Borzhonov v. Russia, No 18274/04 (ECtHR, 22.9.2009) para. 61, Jucys v. Lithuania, No. 5457/03 (ECtHR, 8.1.2008), para. 36).

${ }^{19} 2006 / 783 /$ JHA.

${ }^{20} \operatorname{COM}(2016) 819$ final and Regulation (EU) 2018/1805 of the European Parliament and the Council of 14 November 2018 on the mutual recognition of freezing orders and confiscation orders.
} 
for any particular use. ${ }^{21}$ But they may also be paid into funds particularly aimed at furthering the fight against crime, or at benefitting victims of criminal offences.

In this context the question of so called social re-use of confiscated property may arise. ${ }^{22}$ When assets are re-used for such purposes the assets are not merely transferred to the state budget, but are actually used in a way which is visible to the citizens. This is an initiative that may directly bring back to society some of the proceeds generated by criminal conduct. For example in Italy there is a program on the re-use of property confiscated under the mafia-related confiscation provisions. And in Hungary there is a program on social re-use of contraband, such as clothes and toilet-articles and sanitary products, which are distributed to people in need. ${ }^{23}$ It is also touched upon in Art. 10(3) of the EU's confiscation directive (2014/42/EU):

"Member States shall consider taking measures allowing confiscated property to be used for public interest or social purposes."

The normative force of this section of the Directive is not entirely clear, but even if it is considered too vague to give rise to a duty for member states to implement a social re-use scheme, it would at least seem to suggest that member states undertake an analysis of the feasibility (advantages and disadvantages etc.) of such a regime. ${ }^{24}$

\section{Asset confiscation in Europe: Four generations of rules}

\subsection{Introduction}

The confiscation chain thus involves five stages that all need to function efficiently in order for a confiscation regime to be effective. The purpose of this section is to focus on the third phase of this chain, that is, on the powers awarded to the courts to issue confiscation orders.

Asset confiscation refers in this context to measures that strive at depriving the offender of economic benefit obtained through unlawful conduct, that is, the proceeds of crime (sometimes also referred to as scelere quaesita). The over-arching purpose is, or at least should be, to restore status quo ante (and therefore not to function as an additional punitive measure).

As such, it should be distinguished from other forms of confiscation. Confiscation of instrumentalities (instrumenta sceleris) refers to the deprivation of tools, instruments and other devices or property that have been used to facilitate the commission of an offence. Forfeiture of the product of an offence (productum sceleris) may involve items such as unlawfully produced alcohol or counterfeit money. Confiscation may also target property

\footnotetext{
${ }^{21}$ For an overview of EU practices, see B Vettori, T Kolarov and A Rusev, Disposal of Confiscated Assets in the EU Member States. Laws and Practices (Centre for the Study of Democracy, 2014), p. 39-42. See also B Vettori/A Di Nicola, "The Social Reuse of Confiscated Assets in EU Member States: From Current Experiences to an EU Policy for a "Powered by Citizens" Fight Against Crime, i K Ligeti/M Simonato (red.), Chasing Criminal Money. Challenges and Perspectives on Asset Recovery in the EU (Hart Publishing 2017), s. 321-343.

${ }^{22}$ In the European Parliament resolution of 25 October 2011 on organised crime in the European Union (2010/2309(INI)) social re-use of confiscated assets is asserted that 'the re-use of confiscated assets for social purposes fosters a positive attitude to strategies aimed at tackling organised crime, since confiscating an asset is no longer regarded solely as a means of depriving a criminal organisation of resources but is doubly constructive in that it both helps to prevent organised crime and has the effect of boosting economic and social development'.

${ }^{23}$ See Vettori et al. 2014, p. 74-75, 78-80.

${ }^{24} \mathrm{~S}$ Montaldo, 'The Directive 2014/42/EU and Social Re-use of Confiscated Assets in the EU: Advancing a Culture of Legality, New Journal of European Criminal Law (2015), p. 205.
} 
that has been subjected to an offence, or which it is an offence to possess (corpus delicti or objectum sceleris). This may include contraband, narcotics or stolen property. The purposes and aims of the various regimes differ and each regime should therefore be analysed on its own premises. ${ }^{25}$

It is possible to view the development in Europe of the rules facilitating asset confiscation in terms of four 'generations' (albeit not chronological generations) of confiscation regimes. Each regime moves one step further away from the predicate offence, which allegedly gave rise to the proceeds. The rules relating to asset confiscation can also be viewed in terms of a distinction between criminal confiscation (where confiscation is connected to criminal proceedings based on a criminal offence), preventative confiscation (where confiscation aims at preventing assets from being used for criminal purposes of for furthering crime), and non-conviction based confiscation (where confiscation of criminal proceeds is undertaken outside of the criminal realm in a civil/administrative process) ${ }^{26}$

\subsection{The first generation: Regular criminal confiscation}

The first generation of confiscation rules is constituted by rules that facilitate so-called regular criminal confiscation that follows upon the conviction of a criminal offence. This is an intuitive form of confiscation, which seeks to strip the perpetrator of his ill-gotten gains. Most EU countries today have confiscation rules of this kind in place. The current rules on criminal confiscation are found in Art. 4 of the EU's confiscation directive of $2014 .^{27}$

However, controversial aspects relate, for example, to the principles relating to the quantification of confiscation orders, gross or net (some criminal confiscation schemes clearly have punitive tendencies) and to whether or not confiscation can be ordered even if the respondent lacks responsibility because low age or mental illness. ${ }^{28}$

Typical for this kind of confiscation is, first of all, that it is subject to a final conviction of a criminal offence liable to give rise to economic benefit. Secondly, only proceeds which the state is able to link causally to the offence, of which the defendant has been duly convicted, may be confiscated, for example, the profits from selling a certain amount of narcotic drugs.

\footnotetext{
${ }^{25}$ See further Boucht 2017, p. 14-15. The parallel use of two regimes in one case, which is not unusual, may sometimes also result in asymmetries as regards the distribution of sanctions, particularly in cases with successive acquisitions. Such parallel use can be the case, for example, where the proceeds generated by an offence are confiscated along with the property that has been subjected to an offence (the stolen goods) being forfeited. Consider the following example: $\mathrm{B}$ has stolen certain property from A, and sells it on to $\mathrm{C}$ for $£ 100$. If the $£ 100$ are confiscated as proceeds of crime and the stolen property as objectum sceleris and is passed on back to $\mathrm{A}$, the situation is neutralized save for $\mathrm{C}$, who has both paid $£ 100$ and lost the property.

${ }^{26}$ Similarly also JP Rui and U Sieber, 'Bringing the Picture Together', in JP Rui and U Sieber (eds), Non-ConvictionBased Confiscation in Europe. Possibilities and Limitations on Rules Enabling Confiscation Without a Criminal Conviction (Duncker \& Humblot, 2015), NN

${ }^{27}$ 2014/42/EU. At EU level, the Joint Action of 3 December 1998 on money laundering, the identification, tracing, freezing, seizing and confiscation of instrumentalities and the proceeds from crime (98/699/JHA) was apparently the first legislative instrument to require member states to take the necessary steps to enable confiscation of proceeds of crime and property the value of which corresponded to such proceeds. A similar provision was subsequently included in Art. 3 of the Framework Decision of 2001 on money laundering, identification, tracing, freezing, seizing and confiscation of instrumentalities and the proceeds of crime (2001/500/JHA) and in Art. 2 of the Framework Decision on the confiscation of crime-related proceeds, instrumentalities and property of 2005 2005/212/JHA.

${ }^{28}$ For example Varvara v Italy, App no 17475/09 (ECtHR, 19 October 2013) and G.I.E.M and others v Italy, App No 1828/06 34163/07 19029/11 (ECtHR 28.6.2018), para 241-242 suggest that confiscation in the absence of a mental element is problematic in light of Art. 7.
} 
However, a strict causal requirement may inhibit confiscation for instance in cases where it is difficult to prove that particular assets derive from a specific criminal offence. An example can be where an individual suspected of drug trafficking holds considerable assets, such as a large villa, boat, cars etc., but has no or very limited recorded legitimate income. Even if the assets in question are likely to originate from criminal activity (i.e. the individual possesses property to an extent that is exceedingly disproportionate to his lawful income), a confiscation claim would be rejected under these rules unless the assets could not be linked to the drug offence of which the he is convicted. The same would apply where, for example, money is found in a flat in connection with the investigation of a serious predicate drug offence, but not all of the money can be explained by reference to that offence. With only rules on regular criminal confiscation in place, the benefit exceeding that which may be linked to the predicate drug offence, of which the defendant is duly convicted, could normally not be confiscated.

\subsection{The second generation: Extended criminal confiscation}

As a way of addressing difficulties of this kind, and of making it easier for the state to claim confiscation in certain situations, rules on so-called extended criminal confiscation were introduced. These rules can be referred to as the second generation of confiscation regimes. The main purpose is to target property belonging to career criminals accumulated through unlawful conduct for which a conviction could not be secured.

Extended confiscation was introduced at EU level by Art. 5 of the 2005 Framework decision on confiscation, ${ }^{29}$ and was re-affirmed by Art. 5 of the EU's Confiscation Directive of $2014 .^{30}$ However, rules on extended criminal confiscation were implemented by some European states long before that (for example in the UK by the Drug Trafficking Act 1986 and in Norway in 1998). ${ }^{31}$ Depending on the scheme, this regime may facilitate the stripping of an individual of his entire possessions. It is therefore a potentially very harsh regime. Extended confiscation schemes can also be either property-based, targeting identified property, or value-based.

The main difference, compared to regular criminal confiscation, is that the requirement to concretise the criminal offence in which the assets originate is moderated. Rather than focusing on the benefit from a particular predicate offence, extended confiscation often targets assets stemming from vaguer prior 'criminal activity'. No separate trial and conviction regarding the preceding criminal activity from which the assets allegedly originate is necessary. As the alleged prior criminal activity does not have to be specified, the regime is in fact based on a presumption of prior criminality and gives rise to a certain tension with the presumption of innocence. Traditional criminal procedural safeguards are also usually watered down, often by reversing the burden of proof, for example by means of statutory presumptions, or by lowering the standard of proof. ${ }^{32}$

Extended confiscation is not uncontroversial as it permits confiscation of assets only allegedly linked to past criminal conduct but of which the defendant has not been convict-

\footnotetext{
${ }^{20}$ 2005/212/JHA..

${ }^{30}$ 2014/42/EU. See M Simonato, 'Extended confiscation of criminal assets: limits and pitfalls of minimum harmonisation in the EU', European Law Review (2016), p. 729-735.

${ }^{31}$ For an overview of various extended confiscation regimes, see Boucht 2017, p. 27-65.

${ }^{32}$ For example, statutory presumptions are used under s. 10 of the English POCA 2002 whereas a lowered standard of proof is used in Swedish law.
} 
ed. Extended confiscation, potentially facilitating the stripping of the defendant of his entire possessions, can also be very far-reaching. There have been some challenges in the ECtHR of extended confiscation schemes, but they have for the most part not been successful. ${ }^{33}$ However, in the recent case G.I.E.M. S.r.I. v. Italy the Grand Chamber interpreted Art. 7 so as to require that punishment must include "the existence of a mental link through which an element of liability may be detected in the conduct of the person who physically committed the offence". ${ }^{34}$ This might have consequences for the acceptability under the Convention of extended confiscation, which has previously been considered by the ECtHR to constitute a penalty under Art. 7 (notably in Welch $v$ the United Kingdom) ${ }^{35}$ Even if the Grand chamber in G.I.E.M v. Italy found that its interpretation of Art. 7 does not preclude the existence of certain forms of objective liability stemming from presumptions of liability, provided that it is possible for an individual to exonerate himself from the accusations against him, there is now a clear tension between the requirement that punishment must involve the establishment of guilt and extended confiscation (as a penalty) of proceeds related to alleged criminal conduct of which the defendant has never been convicted.

\subsection{The Third Generation: Non-Conviction Based Confiscation}

The third generation of confiscation regimes are represented by rules on so called nonconviction based confiscation (or NCB confiscation) ${ }^{36}$ Confiscation schemes of this kind have been considered a useful supplementary tool to criminal confiscation in certain situations where it has not been possible to obtain a confiscation order within criminal proceedings.

In Europe, non-conviction based confiscation regimes have been implemented in the UK, Ireland, Italy, Bulgaria and Slovenia. It is also in the process of being implemented in Norway. ${ }^{37}$ At EU level, an NCB confiscation regime was considered in connection with the proposal for the 2014 confiscation directive, but was eventually scrapped ${ }^{38}$ However, the European Parliament and the Council called on the Commission in 2016 to analyse the feasibility, opportunity and possible benefits of introducing common rules on nonconviction based confiscation taking into account the differences between the legal traditions and the systems of the Member States. ${ }^{39} \mathrm{~A}$ feasibility analysis was expected in $2019 .{ }^{40}$

A non-conviction based confiscation scheme differs from its 'criminal' counterparts in several respects. First, whereas in criminal confiscation proceedings, the existence of a predicate criminal conviction is a necessary prerequisite for confiscation, NCB confisca-

\footnotetext{
${ }^{33}$ See Phillips v the United Kingdom , App no 41087/98 ( ECtHR , 5 July 2001), where a far-reaching extended confiscation scheme based on a reversed burden of proof was not considered to deprive the defendant of a fair hearing under Article 6(1). This approach was also used in van Offeren v The Netherlands, App no 19581/04 (ECtHR, 5 July 2005). See also Simonato 2016, p. 735-739.

${ }^{34}$ G.I.E.M. S.r.l. v. Italy, No. 1828/06 34163/07 19029/11, (ECtHR, 28.6.2018), para 242.

${ }^{35}$ Welch v the United Kingdom, App no 1744090 (ECtHR, 9 February 1995). This ruling was upheld in Phillips v the United Kingdom , App no 41087/98 (ECtHR , 5 July 2001). In the case Rt. 2004 s. 1126 the Norwegian Supreme Court found that the extended confiscation scheme under section 68 of the Norwegian Penal Code amounts to a criminal charge under Art. 6(2) of the Convention.

${ }^{36}$ In the US it is often referred to as civil asset forfeiture. See S Cassella, Asset Forfeiture in the US (2015).

${ }^{87}$ For an overview of various NCB Confiscation regimes, see Boucht 2017, p. 67-94.

${ }^{38}$ See COM (2011) 85 final. For a discussion, see M Simonato, Directive 2014/42/EU and Non-Conviction Based

Confiscation, A Step Forward on Asset Recovery?', New Journal of European Criminal Law (2015), p. 220-228.

${ }^{39}$ See Council doc. 7329/1/14 REV 1 ADD 1.

${ }^{10}$ See COM(2016) 829 final, p. 2.
} 
tion is available irrespective of the existence of a criminal conviction. In fact, the confiscation proceedings are often wholly detached from criminal proceedings. No triggering offence is therefore required.

Secondly, whereas criminal confiscation is normally pursued in connection with criminal proceedings, NCB confiscation proceedings are normally pursued outside of the criminal framework, and often as civil proceedings. As civil rules regarding the standard of proof and the admissibility of evidence therefore may apply, the safeguards awarded by the criminal process are often not available. NCB confiscation is normally property based, that is, targeting certain identified property and the burden of proving the unlawful origin of that identified property is normally on the state.

Thirdly, whereas criminal confiscation proceedings, being part of the criminal process, are often in personam, that is, directed against an individual, NCB proceedings are often considered to be in rem. This means that they target the illicit property in question rather than the holder of that property.

Generally speaking there can be two kinds of NCB confiscation schemes. Either retrospective (backward looking) schemes target the proceeds of past crime, however without any requirement to link them to the offence in which the assets allegedly originate. An example of this is civil recovery under Part 5 Chapter 2 of the English POCA 2002. The scheme may also be preventative in nature. In this case, focus is on preventing property from being used to further criminal conduct (although these aspects may intertwine in practice). An example of this is s. 298 of POCA 2002, which facilitates the recovery of cash if the court is satisfied that it is intended by any person for use in unlawful conduct. A preventative NCB confiscation scheme is also in use under the Mafia related legislation in Italy. ${ }^{41}$ Particularly the latter aspect may be seen as a reflection of the preventative tendency in modern criminal law. ${ }^{42}$

The use of NCB confiscation has proved relatively controversial in many jurisdictions, and has been subjected to considerable critique for circumventing basic standards of criminal and criminal procedural law and for blurring the criminal-civil divide. ${ }^{43}$ There have also been a number of challenges in the ECtHR, of both retrospective and preventative NCB confiscation schemes, but they have for the most part not been successful, particularly where sufficient safeguards are in place. ${ }^{4}$ As regards retrospective schemes, the court tends to emphasise that the proceedings do not result in any finding of criminal guilt as well as in their gain neutralising purpose (only assets which do not lawfully belong to the applicant are confiscated). ${ }^{45}$ As regards preventive schemes, the Court, as with the former, often stresses the absence of a finding of guilt in preventative confiscation pro-

\footnotetext{
"See M Panzavolta, and R Flor, 'A Necessary Evil? The Italian "Non-Criminal" System of Asset Forfeiture' in JP Rui and U Sieber (eds), Non-Conviction-Based Confiscation in Europe. Possibilities and Limitations on Rules Enabling Confiscation Without a Criminal Conviction (Duncker \& Humblot, 2015), 111- 48.

${ }^{12}$ U Sieber, "Der Paradigmenwechsel vom Strafrecht zum Sicherheitsrecht", in K Tiedemann, U Sieber, H Satzger, Burchard and Brodowski (eds), Die Verfassung moderner Strafrechtspflege. Erinnerung an Joachim Vogel (2016), 358. ${ }^{43}$ See e.g. I Smith, T Owen and A Bodnar, On Asset Recovery: Criminal Confiscation and Civil Recovery, Binder I (Oxford University Press, 2012a) I-1022, J Lea, 'Hitting Criminals Where it Hurts: Organised Crime and the Erosion of Due Process' (2004) 35 Cambrian Law Review 81, 83 and C King , 'Civil Forfeiture and Article 6 of the ECHR : Due Process Implications for England \& Wales and Ireland’ (2013) 34 Legal Studies 371.

"The requirement of a "mental link" under Art. 7 established by the Grand Chamber in G.I.E.M. S.r.l. v. Italy, No. 1828/06 34163/07 19029/11, (ECtHR, 28.6.2018), para 242 of Art. 7 only becomes relevant where the sanction amounts to a penalty under Art. 7. Consequently, to the extent that a sanction is not a penalty there is no need for first establishing the respondent's personal criminal liability.

${ }^{45}$ See e.g. Walsh v the United Kingdom, App no 43384/05 (ECtHR, 21 November 2006). See also Dassa Foundation and others v Lichtenstein, App no 696/05 (ECtHR, 10 July 2007).
} 
ceedings, and its legitimate purpose, which is to take the assets out of circulation in order to prevent them from being used to facilitate further criminal conduct. ${ }^{46}$

\subsection{The fourth generation: Unexplained Wealth Mechanisms}

The fourth generation of confiscation regimes (although not a confiscation scheme as such but more of a supplementary investigatory regime), is represented by so called unexplained wealth mechanisms. To use unexplained wealth regimes is a relatively new way of pursuing illicit assets and has only been implemented in a few states, such as Australia and Colombia. Recently so-called unexplained wealth orders (UWOs) were also implemented in the UK. ${ }^{47}$

Unexplained wealth mechanisms (UWM) can have different objectives. One is to put the burden on those who are considered to hold unexplained wealth to show the legitimate origin of their assets in order to prevent subsequent civil confiscation. Compared to NCB confiscation proceedings, this kind of unexplained wealth mechanism is brought in personam, targeting the individual, rather than being in rem. In NCB confiscation proceedings the burden of proving the illicit origin of particular identified property is on the state, but may therefore be reversed and thus shifted onto the individual through this mechanism. This is the case for example in the UK regime. The novelty of this scheme in a European setting, may justify a few words about it.

An unexplained wealth order under part 8 of POCA 2002 is an investigatory measure assisting the authorities in the confiscation of assets otherwise difficult to reach. According to s. $362 \mathrm{~B}$, a UWO requires the respondent to provide a statement setting out, inter alia, the nature and extent of his interest in the targeted property, and how he obtained the property. A failure to provide a response gives rise to a presumption that the property is recoverable, in order to assist any subsequent civil recovery action. As such it may perhaps be said the regime operates under a presumption that the identified assets are illicit.

A UWO can be made where the High Court is satisfied that there is reasonable cause to believe that the respondent holds property the value of which is greater than $£ 50,000$, and the court is satisfied that there are reasonable grounds for suspecting that the known sources of the respondent's lawfully obtained income is insufficient for enabling the respondent to obtain that property.

UWOs are available against two kinds of respondents. Either so called politically exposed persons ('PEPs'), that is, individuals who are, or have been, entrusted with prominent public functions by an international organisation or by a State other than the UK or another EEA State, a family member or a close associate of such persons, or someone otherwise connected with such persons. The target is, for example a corrupt state official who has invested larger sums in London, but where a criminal conviction is unlikely to be attained from the home country and where it is difficult to prove, on a balance of probabilities by presenting clear and cogent evidence, that the assets are or represent the proceeds of crime.

\footnotetext{
${ }^{16}$ See e.g. Arcuri and others v Italy, App no 52024/99 (ECtHR, 5 July 2001) and Butler v the United Kingdom, App no 41661/98 (ECtHR, 27 June 2002).

${ }^{17}$ Sections 1-6 of the Criminal Finances Act 2017 introduced new sections 362A - 362R and 396A - 396U of POCA 2002.
} 
However, a UWO may also be issued where there are reasonable grounds for suspecting that the respondent is, or has been, involved in serious crime (whether in a part of the UK or elsewhere), or a person connected with the respondent is, or has been, so involved. The meaning of serious crime is understood in accordance with Part 1 of the Serious Crime Act 2007. This definition is fairly wide and involves, inter alia, drugs and people trafficking, firearms offences, prostitution and child sex offences, money laundering, fraud, armed robbery, bribery, computer misuse and counterfeiting.

The other objective of introducing UWMs is to criminalise unexplained wealth. This means that the failure to prove the licit nature of the means constitutes an offence in itself. Criminalising unexplained wealth has been considered useful in order to fight corruption of state officials as the difficulty of obtaining evidence in these cases may impede criminal prosecutions. ${ }^{48}$ As such, Art. 20 of the UN Convention against Corruption 2000, advises states to consider, subject to its constitution and the fundamental principles of its legal system, criminalising unexplained wealth in relation to (domestic) public officials.

In such a framework, the state will have to prove to the criminal standard that the wealth is unexplained, but there is no need to prove the source of the illegally acquired wealth by identifying and proving the predicate offenses, which may comprise, for example, bribery, embezzlement or abuse of state functions. If the state manages to show that the individual's assets are disproportionate to his legitimate sources of income, a presumption of these assets being illicit is triggered. In order to avoid conviction, the individual will have to prove that is wealth is of a legitimate origin.

It follows that the effect may extend beyond corruption and would therefore allow states to confiscate criminal proceeds relating to other crimes. ${ }^{49}$ Indirectly, therefore, the scope of the regime becomes very wide. It also follows that the assets in this case can be confiscated by way of regular criminal confiscation.

\section{Challenges relating to the expansion of regimes aimed at the confiscation of criminal proceeds or criminals' proceeds}

\subsection{Introduction}

As can be seen, the net is tightening around criminal money. The mechanisms potentially available today for stripping individuals of suspected criminal wealth are very farreaching indeed. In fact, if used to their full extent it seems somewhat difficult to imagine how these measures could be made even more extensive.

I will in the following attach some remarks to three general challenges relating to the current development of schemes for making confiscation of criminal proceeds more effective. The first concerns two practical issues relating to efficiency. The second relates to the knowledge base underlying the tendency of implementing ever more far-reaching confiscation schemes: how far is it actually necessary to go? The third, and interlinked, issue consists of a more principally based concern relating to the protection of the confiscation subject's rights. That is, how can we create confiscation schemes that are effective but nevertheless sufficiently respect and safeguard individual rights?

${ }^{18}$ See L Muzila, M Morales, M Mathias and T Berger, On Criminalizing Illicit Enrichment to Fight Corruption (StAR Initiative 2012), p. 6-7.

${ }^{19}$ Muzila et al. 2012, p. 7. There is therefore a similarity to money laundering in that there is no need to prove an underlying offense, although the criminal nature of the funds still need to be proven. 


\subsection{Practical challenges}

In spite of the potentially very far-reaching mechanisms for targeting illicit money available today, a considerable share of criminal proceeds still seem to remain in the hands of perpetrators. In fact, existing confiscation regimes are often criticised (internationally, at the EU level and at national levels) for not being sufficiently effective. In reaching such conclusions, it is often drawn upon the weak ratio of confiscated assets to the amount of total criminal wealth. For example, a recent EU document suggested that illicit markets in the European Union generate about 110 billion EUR, but that $98.9 \%$ of these criminal profits are not confiscated and remain at the disposal of criminals. ${ }^{50}$ The response is often new legislation conferring ever broader confiscation powers on the courts.

How then to make confiscation more effective? This is, of course, the $£ 10.000$ question that has no clear and easy answer. However, it is possible to point at certain practical challenges that may impede the effective confiscation of criminal assets. As indicated above in section 2, the confiscation process consists of a number of stages, and in order for the system to be efficient the entire chain must function efficiently. The efficacy of asset confiscation regimes is therefore not solely contingent on the legal powers conferred upon the courts. It would, however, seem that each stage of this chain has its own challenges (which include the international dimension of many criminal asset investigations).

It is, first of all, an essential prerequisite for effective confiscation of criminal proceeds that assets potentially liable to confiscation are traced and found during the investigative phase. There can be many reasons for assets not being found. The mind-set of investigating police officers, even of officers specialising in economic crime, may be focused more on investigating the criminal offence than on the proceeds it has generated. Financial investigations may be limited to certain kinds of offences (for example particular kinds of financial offences rather than any offence liable to produce economic gain) and/or even be considered a distraction, because they divert time and resources away from the criminal investigation. Financial investigations may also be initiated too late in the process (or not at all), rather than being carried out in tandem with the criminal investigation. There may, moreover, be a lack of resources in the investigating units, so that when the money trail is complicated, the benefit involved does not appear considerable or the assets are located abroad, other tasks are prioritised. Access to crucial information, essential to the success of financial investigations, can furthermore be inadequate. The free flow of information from government agencies (such as tax or social welfare authorities) to the investigating authorities may, for example, be hampered by 'watertight bulkheads' between bodies. Lastly, the increase in transnational crime has made confiscation matters, including financial investigations, more complicated and international cooperation more important. ${ }^{51}$ Perpetrators may (and often do) transfer assets abroad, to their home countries, to relatives, or to or through shell companies registered in tax havens, with limited transparency as regards for example beneficial ownerships, in order to make it more difficult for the national authorities to trace them. The attempts to disguise illicit assets may be elaborate and can require considerable efforts by investigators to uncover.

\footnotetext{
${ }^{50} \operatorname{COM}(2016)$ 819, p. 2.

${ }^{51}$ For an overview as regards international cooperation in financial investigations, see J Boucht , 'European Cooperation in Financial Investigations - An Overview of the Legal Foundation and Future Challenges' in Z Durdevic and EI Karas (eds), European Criminal Procedure Law in Service of Protection of European Union Financial Interests: State of Play and Challenges (Croatian Association of Criminal Law , 2016 ) 117 - 31 .
} 
It follows that one important first step is to make the investigative step effective, and to seek to avoid that, inter alia, the obstacles mentioned above impedes the identification of criminal proceeds. Adequate training would also seem to be a key word in this regard.

Second, the powers to freeze and seize the assets should be sufficient in order to prevent the dissipation of identified assets, both nationally and internationally. For example, a decision to freeze property may mean that notice is served to the owner/holder of the property. But where the circumstances are such that notice would prejudice the interests of the enforcement authority to obtain a confiscation order in respect of any property freezing, it should be possible to make a freezing order also without notice.

As assets may be located abroad, it is also necessary that freezing decisions can be executed in the relevant state with certain promptness. However, one problem facing judicial freezing orders that are to be executed abroad is that they need to be judicially approved in the requested state before they can be executed. This can be time consuming. As noted above, the 2003 FD on the execution of orders freezing property or evidence stipulates that the principle of mutual recognition also applies to pre-trial freezing orders issued within the EU for the purpose of securing subsequent confiscation of property. ${ }^{52}$ However, it would seem that the freezing FD has not been utilised by member states to any considerable extent, probably partly because of the relatively slow process involved. It also seems that the instrument is considered complicated and insufficient, and that member states therefore often revert to standard MLA proceedings. ${ }^{53}$ These aspects point at the need for smoothness in international cooperation. Some of them will probably be remedied by Regulation (2018/1805) on the mutual recognition of freezing orders. ${ }^{54}$ The EU has been an important player in improving the infrastructure between EU states, but where assets are located outside of Europe things may be less smooth running.

Although freezing is an important measure, a delicate balance has to be struck. Premature seizure or freezing may be harmful for the respondent, particularly where the state is permitted to sell of property before the final judgment in the matter, e.g. where the measure targets entire businesses. It is therefore important that due process is respected when seizure and freezing is ordered and that sufficient safeguards, for example, the right to challenge the decision and to get a reasoned decision from the court within a reasonable time, are available. It is also important that the state exercises due care as regards management of the seized assets. The management of seized assets may however be challenging for the agency entrusted with it in situations where the property seized involves, for example, livestock, entire businesses, entire ports or entire windmill farms. Also the uncertainty linked to whether subject will be convicted, for example in complex economic crime cases, and the length of the proceedings may be challenging for the responsible management agency.

Third, it is important that the courts as well as the prosecutors or other responsible agencies use the existing confiscation powers to their full extent, albeit showing due consideration for proportionality and fairness considerations. For this to happen, it is important

\footnotetext{
${ }^{52} 577 / \mathrm{JHA}, 22.7 .2003$.

${ }^{33}$ See e.g. COM(2008) 766 final, 4 and Europeiska rådet, Slutrapport om den femte omgången av ömsesidiga utvärderingar - Ekonomisk brottslighet och finansiella utredningar, 12657/2/12 (REV2) 3.1.0.2012, p. 14. One of the problems with the freezing FD as regards the freezing of evidence has been the lack of mechanisms for transferring the evidence to the requesting state. This shortcoming, whereby evidence is not sent in the same way as in freezing with the purpose of confiscation, has been addressed in the European Investigation Order (Directive 2014/41/EU).

${ }^{34}$ COM (2016) 819 final and Regulation (EU) 2018/1805 of the European Parliament and the Council of 14 November 2018 on the mutual recognition of freezing orders and confiscation orders.
} 
that the bodies responsible for enforcing the policy have sufficient knowledge of the existing legal scheme(s). Training is therefore a key word in this context as well. It is important that the state has sufficient powers to confiscate criminal proceeds, potentially also in the absence of criminal convictions, however without being overly repressive. As regards the level of development of confiscation schemes, there is a considerable difference between states, even within the EU (which may give rise to obstacles in cooperation).

Fourth, when the confiscation order has been made, it is important that the order is enforced, both nationally and internationally, that is, that the asset are in fact collected. Enforcing the confiscation order would, however, seem to represent an Achilles heel in some countries with only parts of the total amount of confiscation orders actually enforces. For example statistics from the national enforcement agency in Norway indicate that only approximately $30 \%$ of the assets ordered confiscated are in fact collected. Also in the UK the authorities are struggling with nearly 2 billion GBP unsatisfied criminal confiscation orders. The reasons for this may be manifold, but may in any case reduce the large confiscation ambitions at the decision stage to symbol politics at the enforcement stage.

When assets are located abroad on the territory of another state, an important element, and potential obstacle, in this phase concerns the recognition in one state of a confiscation order issued in another state. According to the EU's 2006 Framework Decision on the mutual recognition of confiscation orders, the principle of mutual recognition should apply also to confiscation orders. ${ }^{55}$ However, the grounds for non-execution under the FD are several, and problems have arisen for example in situations where the executing state does not recognise the kind of confiscation order issued in the issuing state, for example, so-called non-confiscation based confiscation orders. ${ }^{56}$ As mentioned earlier, the Regulation (2018/1806) on the mutual recognition of freezing and confiscation orders covers both the freezing process and the mutual recognition of confiscation orders. ${ }^{57}$ The regulation applies to all confiscation orders issued within the framework of proceedings in criminal matters, and as such not only to conviction-based confiscation, but also to non-conviction based confiscation orders, also where such orders might not exist in the legal system of a member state and will therefore clear some previous obstacles. ${ }^{58}$

Outside of Europe, the procedures involved getting a confiscation order recognised might be more cumbersome.

Also the fifth phase, the disposal phase, may be connected with challenges. For example, the confiscated property (particularly real estate) may be mortgaged or shared, or there may be third-party claims to the property. Neither is the social re-use of confiscated assets frictionless, as Vettori et al. observe, because of for example

"mortgage liens and third party claims to the property which have to be settled or otherwise transferred to the final beneficiaries (Italy); rapid deterioration or bad condition of the assets, which makes them unattractive for re-use or entail additional costs for restoration (Italy); infringement of property rights in cases involving counterfeited goods, which precludes gratuitous transfer or in any case necessitates the removal of branding, which may also be costly (Hungary, Lithuania).“ ${ }^{59}$

\footnotetext{
${ }^{35}$ 2006/783/JHA.

${ }^{56}$ See above in section 3.4.

${ }^{57} \mathrm{COM}(2016) 819$ final.

${ }^{58}$ See PE-CONS No/YY - 2016/00412(COD), preamble s. 13.

${ }^{39}$ Vettori et al. 2014, p. 39.
} 


\subsection{The knowledge-base}

As noted above, existing confiscation regimes are often criticised for not being sufficiently efficient. What does efficiency in this field then mean? ${ }^{60}$ Do we, for example, refer to the capacity of confiscation to deter potential offenders from engaging in acquisitive crime? Or do we mean the efficiency with which future offences are prevented from being committed by removing the means for facilitating unlawful conduct? Or do we refer to the effectivity in taking out of circulation criminal money, that is, restoration of status quo ante. It would seem that all three aspects could be relevant.

As regards the deterrent effects of confiscation, there is generally a strong belief that confiscation will reduce crime by removing the economic incentive to commit acquisitive crime. Indeed, a system that permitted criminals to retain the fruits of their crime would undoubtedly send an unfortunate message not only to potential criminals, but also to the population at large. ${ }^{61}$ However, although intuitively a powerful assumption, there seems to be relatively little hard evidence available about the actual effects of asset confiscation on criminal conduct, not only as regards its deterrent effects. Neither do we know a great deal about how effective confiscation is for preventing future wrongdoing, or about the effectivity in achieving the restorative aim (i.e. how big a share of criminally obtained wealth is actually confiscated).

As regards effectivity with regard to fulfilling a restorative aim, one way to assess the efficiency, or lack thereof, of confiscation schemes is to calculate the changes in the amount of criminal wealth as a result of the existing confiscation measures being applied. That is, the ratio of confiscated assets to the amount of total criminal wealth. A conclusion of the inefficiency of existing rules is in fact often based on the alleged limited size of confiscated assets. For example a recent EU policy paper claimed that only $1,1 \%$ of the illicit assets in circulation in the EU are confiscated. ${ }^{62}$

However, although often referred to as a yardstick of the efficacy of confiscation regimes, such assessments can be encumbered by methodological weaknesses giving rise to doubts about their accuracy. First of all, this kind of assessment requires that the amount of confiscated assets is ascertained. Although this should in principle be manageable, it would seem that it is in fact not always an entirely effortless exercise. Assessing the extent of criminal wealth in existence can be (even more) difficult. Because of the difficulty of obtaining reliable data, estimates will ultimately rest on a number of presumptions, such as the extent of the flow of criminal money and the profit margin involved. The estimates of criminal turnover therefore easily become speculative and possibly, perhaps even probably, exaggerated. The assessment can be further more obstructed by the fast that crime, and confiscation, often has a transnational nature.

Particularly in regard to preventive confiscation Naylor further convincingly points out that before anything really can be said of the efficiency, or lack of it, of a confiscation regime, a comparison should also be made between the rate of growth of criminal income relative to legal income to ascertain if the part taken out of criminal wealth is actually af-

\footnotetext{
${ }^{60}$ For a discussion on the various purposes of confiscation, see Boucht 2017, p. 96-115.

${ }^{61}$ Boucht 2017, p. 10.

${ }^{62}$ See e.g. COM(2016) 819 final, p. 2.
} 
fecting adversely the ability of the illegal market to operate. ${ }^{63}$ This calculation may, however, be difficult to perform. ${ }^{64}$

The relative absence of empirically founded facts is far from ideal. Criminal justice policy should be knowledge-driven and rational. Reforms, for example when making existing confiscation schemes more repressive or introducing new ones, should therefore be based on knowledge and actual needs, and not be merely symbolic. Thus, as Naylor forcefully argues, it would be reasonable to expect that the state does not deploy more far-reaching measures,

\footnotetext{
"unless and until their need has been unambiguously established, their objectives clearly delineated, and the public well informed both of their actual (as distinct from purported) purpose and of any ' collateral damage ' their use might entail. It should be first convincingly demonstrated that any perceived failure of existing methods of crime control results from deficiencies of existing laws, rather than from deficiencies in the application of existing laws, that a crisis exists of sufficient order of magnitude to require radical alternatives, and that such alternatives have a good chance of being effective in rectifying those deficiencies., ${ }^{65}$
}

In light of this, there is a need for more (empirical) research on the effects of asset confiscation on crime levels. Such knowledge would assist not only governments when seeking to make confiscation more effective, but also the academic community when assessing these various schemes.

A move to implement more far-reaching confiscation regime should therefore be preceded by careful consideration of the actual need for implementing it. Research indicates that the insufficient insight into the effects of existing schemes may result in the implementation of unnecessary measures ${ }^{66}$ Furthermore, more severe rules do not necessarily per se result in a higher output. However, where the confiscation powers implemented by a state are insufficient, for example by not permitting confiscation in cases where it should have been ordered, introducing new schemes should be considered.

\subsection{Principled concerns}

The third aspect I wish to point at is of a more principled nature. Even if the increased focus on criminal proceeds, and development towards more effective confiscation regimes, is positive as such, it does not come without a number of concerns in its wake. The question is:

How far can we go in circumventing, or diluting, traditional criminal law standards in the field of asset confiscation, before we leave the domains of a liberal criminal law in the tradition of a democratic Rechtsstaat based on the rule of law?

These criminal law standards were obviously put in place for a reason, namely to protect individuals from being wrongfully convicted of an offence because of the hardship that punishment imposes, and the social stigma that follows upon a criminal conviction. However, there is a tendency today to emphasise the difference between asset deprival

\footnotetext{
${ }^{63}$ Naylor 1999, s. 16.

${ }^{61}$ See for discussion Naylor 1999, p. 15-25.

${ }^{65}$ RT Naylor, 'Wash-out: A Critique of Follow-the-Money Methods in Crime Control Policy' (1999) 32 Crime, Law and Social Change 1, p. 3.

${ }^{66} \mathrm{H}$ Nelen, 'Hit Them Where it Hurts the Most? The Proceeds-of-Crime Approach in the Netherlands' (2004) 41 Crime, Law \& Social Change, p. 526
} 
and the establishment of criminal liability in the sense that the former requires fewer safeguards to be put in place. Thus, the traditional Blackstonian standard of rather acquitting 10 guilty persons than wrongly convicting one innocent does not apply, at least not with the same force, in the field of asset confiscation.

An important policy question is therefore what we perceive the correct distribution of error to be in confiscation proceedings. That is, what kind of risk of targeting assets, which are in fact legitimate, is acceptable? The more we dilute the safeguards, the more we increase the risk of wrongful confiscation decisions. And where legitimate property is in fact wrongly confiscated, the individual's right to property under Art. 1 ECHR-P1 is in principle violated.

There is a tension between the interests involved. The modern society with its complex economic (cyber)crime, transnational crime, terrorism etc. requires new kinds of crime control mechanisms to be put in place. It is also true that there is a difference in principle between measures aiming at the establishment of criminal guilt and those targeting allegedly illicit assets. However, even if such a difference is acknowledged, and even if it is accepted that the distribution of error may not have to be identical with that of core criminal law responsibility, it should in view of the potential far-reaching consequences that these measures potentially have nevertheless be critically analysed how far such arguments can be legitimately used in justifying the dilution of procedural safeguards in asset confiscation proceedings. Moreover, what kind of safeguard regimes should be employed: a light version of the safeguards of the criminal process, ${ }^{67}$ or a particular safeguard regime that is developed and tailored for each alternative sanctioning regime?

One element of a criminal sanction is that it brings with it some kind of hard-ship, either as a restriction of the right to free movement or in the form of a monetary liability. The idea is to put the defendant in a worse position than he was prior to having been subjected to the sanction. ${ }^{68}$ One important issue that arises is therefore whether or not a confiscation measure should be limited to restore status quo ante or in fact impose more farreaching detriment on the confiscation subject than is necessary for fulfilling a restorative aim, and thus to place the offender in a worse economic position than he held prior to engaging in the unlawful conduct. ${ }^{69}$ Where the measure is restorative it only takes away what the respondent is not entitled to possess, and can hardly, on any account, be considered punitive. ${ }^{70}$ Where confiscation, on the other hand, is not limited to actual enrichment and the subject thus faces more far-reaching detriment as a result of the confiscation order than that to which he was exposed at the time of committing the offences of which he was convicted, there are good reasons to argue that the order is in fact punitive. ${ }^{71}$

In the field of asset confiscation there are good reasons for arguing that confiscation for the purpose of depriving the perpetrator of ill-gotten gains (backward-looking restoration) should be limited to gain neutralisation, i.e. to restore status quo ante by targeting only

\footnotetext{
${ }^{67}$ In Jussila v Finland, App no 73053/01 (ECtHR, 23 November 2006), para. 43 the ECtHR acknowledged that not all criminal law belongs to the 'the core' where the safeguards must apply with the same stringency.

${ }^{68}$ See R Bowles, M Faure, and N Garoupa, 'Economic Analysis of the Removal of Illegal Gains' (2000) 20 International Review of Law and Economics 537, 539-42

${ }^{69}$ See Boucht 2011, s. 119-129. See also Rui/ Sieber 2015.

${ }^{70}$ See also e.g. Dassa Foundation and others v Lichtenstein, App no 696/05 (ECtHR , 10 July 2007).

${ }^{71}$ See e.g. Welch v the United Kingdom, App no 1744090 (ECtHR, 9 February 1995) compared with Dassa Foundation and others v Lichtenstein, App no 696/05 (ECtHR, 10 July 2007).
} 
net profits. ${ }^{72}$ In this case confiscation gets a restitutive nature. It should be for the realm of punishment proper to add further detriment to the defendant.

The diluted safeguards inherent in some of these regimes, especially in combination with a weaker connection to a prior unlawful conduct, increase the risk that the confiscation measure targets also other assets that criminal gain (i.e. legitimate assets). Many confiscation regimes today include elements of either a lower standard of proof (a balance of probabilities rather than one that approaches the criminal standard) and/or a reversed burden of proof as regards the origin of the assets in question. However, what the standard of proof should be in confiscation proceedings, and whether or not a reversed burden of proof can be justified, is disputed.

It can, as a starting point, be argued that the right to property suggests that due to the risk of targeting legitimate property, confiscation should not be permitted unless it is sufficiently probable that the assets in question are of an illicit nature, because otherwise it cannot be necessary to change the legal ownership of an item. In this context, therefore the 'contextual assumption', or the inherent likelihood, that the assets in fact are or represent criminal profits, should also be given relevance. Thus a distinction would be made between cases where there is either a triggering offence or a criminal record relating to acquisitive crime, and cases where there is neither a triggering offence nor a criminal record. The existence of prior acquisitive criminality might make it less controversial to employ a lower standard of proof or even a reversed burden of proof.

However, where the link to actual criminality, and therefore the contextual assumption, is weak, the point of departure should be that more is required from the state before confiscation can be ordered. This could involve that clear and cogent evidence that the assets are illicit is required (or that the standard of proof is formulated, for example, as a qualified balance of probabilities) and that the burden of proof is not reversed. However, to the extent that the scope (or 'target area') is limited only to a certain kind of particularly exposed persons, such as political officials or certain kinds of more serious offences, it may still not be unfair to base a confiscation decision even in such a case on a reversed burden of proof where it is reasonable to expect the respondent to provide an explanation of the provenance of the assets. Fairness in this context is about finding a reasonable balance between the interests involved and the existence of compensating mechanisms. ${ }^{73}$ However, a procedurally fair system does not as such compensate for a substantively unfair regime.

The diluted safeguards inherent in some of these regimes also create a direct tension with the right to a fair trial under Art. 6 ECHR. For example extended criminal confiscation, which potentially may lead to the stripping of the defendant's entire wealth is based on a presumption of prior criminality. Where unexplained wealth has been criminalised, criminal liability is in fact based on a reversed burden of proof, making it easier for the prosecution to prove beyond reasonable doubt that the defendant's assets were obtained using criminal proceeds (as they do not have to prove that bribes have actually changed hands). ${ }^{74}$ Conviction in such a case would, however, seem to rest on dubious grounds as a

\footnotetext{
${ }^{72}$ See Boucht 2017, s. 99-101.

${ }^{73}$ Se Boucht 2017, p. 141-231 for a balancing model with regard to the legitimacy of extended appropriation schemes.

${ }^{74}$ M Fernandez-Bertier, 'The confiscation and recovery of criminal property: a European Union state of the art', ERA

Forum (2016), at note 64 .
} 
reversal of the burden of proof would create a tension to not only the presumption of innocence, ${ }^{75}$ but also to the privilege against self-incrimination under Art. $6 \mathrm{ECHR}^{76}$

Another point of concern is that the scope of confiscation regimes may be very wide. Indeed, it is not unusual that far-reaching regimes are introduced under the rhetoric that they are intended to target only serious and organised crime, but are subsequently expanded to cover also other offences. Such a development can be seen for both extended criminal confiscation and NCB confiscation. Also the UK's unexplained wealth mechanism is potentially very far-reaching considering that its scope of application does not only cover PEPs, but also individuals reasonably suspected of serious crime based on a wide definition of that concept. However, already some years ago the extensive UK confiscation regime was criticised for catching very few, if any, Mr. Big's, while the main bulk of confiscation proceedings related to only small fish, or even plankton. ${ }^{77} \mathrm{~A}$ wide scope in combination with diluted safeguards and a weak link to prior criminality creates a farreaching and potentially repressive system.

The scope of a scheme also involves the question of whether or not innocent (third) parties are protected. Third party criminal confiscation may be important where criminal proceeds have been transferred, directly or indirectly, to third parties in order to avoid confiscation. In NCB confiscation it may simply refer to anyone who holds tainted property. Bona fide protections are often linked to notions of fairness, but, in a European context, also to the right to property under Art. 1 ECHR-P1. The rights of bona fide third parties should therefore reasonably be protected so that confiscation is only permitted, for example, where the third party knew or ought to have known, on the basis of concrete facts and circumstances, that the purpose of the transfer or acquisition was to avoid confiscation. ${ }^{78}$ Within the EU, this follows from Art. 6 of the EU's Confiscation Directive. The Directive specifies that relevant circumstances that may trigger confiscation are that the transfer or acquisition was carried out free of charge or in exchange for an amount significantly lower than the market value.

Also the proper relationship between NCB confiscation and criminal confiscation proceedings may give rise to concern. That is, should criminal proceedings always first be sought pursued or not? In England, for example, there was a fear that NCB confiscation would be used in place of criminal proceedings when the POCA 2002 was introduced. However, this does not seem to have materialised, possibly as a consequence of the legislative steer that s. 2A in Part 1 of POCA 2002 sets out in directing criminal proceedings to be brought wherever possible. ${ }^{79}$ However, in some other Anglo-American jurisdictions, it would seem that civil confiscation has in fact replaced criminal confiscation as the main

\footnotetext{
${ }^{75}$ See D Thomas-James, 'Unexplained Wealth Orders in the Criminal Finances Bill: a suitable measure to tackle unaccountable wealth in the UK?', Journal of Financial Crime (2017), 179.

${ }^{76}$ On the privilege against self-incrimination, see e.g. S Trechsel, Human Rights in Criminal Proceedings (Oxford University Press, 2006), p. 340-349.

"See PA Sproat, 'To What Extent is the UK' s Anti-Money Laundering and Asset Recovery Regime Used Against Organised Crime?' (2009) 12 Journal of Money Laundering Control 134 - 50.

${ }^{78}$ For a discussion, see e.g. Boucht 2017, p. 156-159, 209-213.

${ }^{79}$ See Smith et al, On Asset Recovery, III-2005. Moreover, in the Attorney-General's guidance to asset recovery powers for prosecutors issued by the UK Attorney-General's Office (29 November 2012), available at www.gov.uk/guidance/asset-recovery-powers-for-prosecutors-guidance-and-background-note-2009, criminal proceedings are considered primary to civil recovery proceedings. Para 1 states, 'The reduction of crime is in general best secured by means of criminal investigations and criminal proceedings. However, the non-conviction based asset recovery powers available under the Act can also make an important contribution to the reduction of crime where (i) it is not feasible to secure a conviction, (ii) a conviction is obtained but a confiscation order is not made, or (iii) a relevant authority is of the view that the public interest will be better served by using those powers rather than by seeking a criminal disposal.'
} 
measure for stripping suspected offenders of their ill-gotten gains, because of the moderated evidential requirements compared to criminal confiscation proceedings.

This is not an unproblematic development. NCB confiscation may be an alternative to criminal confiscation proceedings in some situations (for example where the defendant has absconded or died, or where he resident abroad), but there are good reasons to argue that it should, as a main rule, remain supplementary and not become a substitute (for example, for reasons of convenience) for criminal proceedings in cases that should properly be dealt with within the criminal framework. ${ }^{80}$

In some cases preventative confiscation may be necessary. ${ }^{81}$ However, the introduction of preventative schemes can be problematic because of the inherent uncertainty connected with predicting future actions and future use of the assets in question, particularly where the contextual assumption of the assets' being illicit is weak, such as where the respondent has no criminal record ${ }^{82}$ It may also be difficult to determine which potential acts need to be prevented and which proceeds need be confiscated for achieving that aim? As the purpose is to prevent assets from being used to further criminal conduct, the focus easily indirectly turns on the individual holding the assets, rather than being on the unlawful nature of the property.

Such schemes may also create procedural difficulties for the respondent. Case law from the ECtHR's suggests that it essential from the point of view of Art. 6 that it is reasonably possible for the individual to exonerate himself from a claim made against him, and that such a rebuttal should not amount to his bearing an individual and excessive burden. ${ }^{83}$ However, in pure preventative confiscation schemes, where there is no link to past unlawful conduct, it may be difficult for the respondent to disprove the claims made against his property based on claims about not-yet-realised future behaviour. ${ }^{84}$

A third concern relates to the (potential) lack of inherent limits when pursuing preventive aims. Hassemer, in noting the exorbitance and empiric foundation of preventionism in criminal law, puts it aptly:

\begin{abstract}
"The main normative problem of the prevention paradigm ... is its exorbitance. The limit of the threat of deterrence and the end of the efforts to re-socialize are nothing other than the respective entrance of the success, the realisation of the preventive purpose; the limits of prevention are determined by empirical, not by normative parameters. Unlike a criminal law response based on retribution, which finds its limits in itself because it must be appropriate to what it responds to, prevention has no antenna for excess. [translated by the author] ${ }^{\$ 5}$
\end{abstract}

In light of the foregoing, asset confiscation should arguably primarily be conducted on a backward-looking basis, so that the primary purpose and justification is to recover the economic benefit obtained through unlawful conduct. The use of pure preventive confis-

\footnotetext{
${ }^{80}$ Boucht 2017, p. 72.

${ }^{81}$ For example in Italy preventative confiscation is utilised in the fight against the Mafia. See Raimondo v Italy, App no 12954/87 (ECtHR, 22 February 1994), M v Italy, App no 12386/86 (ECtHR, 15 April 1991) and Arcuri and others v Italy, App no 52024/99 (ECtHR, 5 July 2001). See also Panzavolta/Flor 2015.

${ }^{82}$ Boucht 2017, p. 112-113.

${ }^{83}$ See e.g. Janosevic v Sweden, App no 34619/97 (ECtHR, 21 May 2003),para. 101(2). In G.I.E.M and others v Italy, App No 1828/06 34163/07 19029/11 (ECtHR 28.6.2018), para. 243, this requirement is connected also to Art. 7.

${ }^{8}$ A Ashworth and L Zedner, PReventive Justice (OUP, 2014), p. 20-25 note that preventive measures may at some point reach a stage where their coercive nature is such that the subject ought reasonably to be awarded a higher level of protection.

${ }^{85}$ W Hassemer, 'Strafrecht, Prävention, Vergeltung' (2006) 7 Zeitschrift für Internationale Strafrechtsdogmatik 266, 270 .
} 
cation schemes should require particular justification. ${ }^{86}$ Another thing is that a backwardlooking scheme will also fulfil preventative purposes.

Moreover, the potential stigmatising effects, as well as the negative effects of confiscation on an individual's reputation of being subjected to confiscation should not be underestimated. This does not only apply to criminal confiscation, but also to for example NCB confiscation proceedings, where the holder of the property is in effect singled out as having been associated with criminal activity. Conceptual re-labelling from criminal to civil does not necessarily affect the factual perception of the measure.

Lastly, the potential adverse social effects on individuals liable to confiscation (of all kinds) should not be disregarded. Such effects may relate to the re-socialisation of offenders into society, the social situation of the respondent (losing considerable wealth may lead to divorce, loss of a job, or even suicide) and the impact on family members (for example, where the family home is confiscated). Circumstances such as these have, for example, commendably been taken into account by the Swedish Supreme Court in quantifying criminal confiscation orders. ${ }^{87}$ Confiscation schemes should therefore generally be subjected to a fairness requirement. ${ }^{88}$

Many of the challenges in the ECtHR of various confiscation regimes have failed. However, the ECtHR has also set important limits to how confiscation is practised. The Court has, inter alia, concluded that extended criminal confiscation is to be characterised as a criminal penalty, ${ }^{89}$ that a criminal penalty cannot be imposed without a guilt element (a 'mental' or 'intellectual' link), ${ }^{90}$ that ordering confiscation in a situation where neither the alleged profits nor the commission of the offence had been proved amounts to a violation of Art. 6(2), ${ }^{91}$ and that a proportionality assessment under Art. 1 ECHR-P7 is required in confiscation proceedings. ${ }^{92}$

Yet, the acquitting conclusions in some cases would seem not to be unequivocal. Arguably, the ECtHR has shown a readiness to display considerable deference towards how states construct and use asset confiscation as a means of crime control. ${ }^{93}$ The principles underlying the Court's jurisprudence have also been criticised for being both vague and sometimes contradictory. ${ }^{94}$ For example, Ivory finds that 'the rationale behind the ECtHR's classification scheme is obscure, if not incoherent and inconsistent ${ }^{95}$ The jurisprudence of the ECtHR is therefore not necessarily as powerful a restraint in the field of confiscation as it may be in other fields of criminal proceedings. As such, and particularly

\footnotetext{
${ }^{86}$ On prentive measures and safeguards, see A Ashworth and L Zedner, Preventive Justice (Oxford University Press, 2014), p. 20-25.

${ }^{87}$ See e.g. case NJA 1977 s 735

${ }^{88}$ Boucht 2017, p. 182-185, 218-219.

${ }^{89}$ Welch v the United Kingdom, App no 17440/90 (ECtHR, 9 February 1995) and Phillips v The United Kingdom, App no 41087/98 (ECtHR, 5 July 2001).

${ }^{90}$ Varvara v Italy, App no 17475/09 (ECtHR, 19 October 2013) and G.I.E.M and others v Italy, App No 1828/06 34163/07 19029/11 (ECtHR 28.6.2018), 241-242,

${ }^{91}$ Geerings v The Netherlands, App no 30810/03 (ECtHR, 1 March 2007).

${ }^{92}$ Paulet v the UK, App no 6219/08 (ECtHR, 13 May 2014).

${ }^{93}$ In addition, it seems that the Court has identified certain areas where effective measures have been deemed particularly pressing, such as drug trafficking, bribery and organised crime, where it seems that tolerance is even higher. For example as regards organised crime, see Raimondo v Italy, App no 12954/87 (ECtHR, 22 February 1994) para 30, and Arcuri and others v Italy, App no 52024/99 (ECtHR, 5 July 2001). For a similar argument, see also Panzavolta/Flor 2015 , p. 146.

${ }^{91}$ For an overview, see Simonato 2017, p. 369-373.

${ }_{95}^{9}$ R Ivory, Corruption, Asset Recovery, and the Protection of Property in Public International Law: The Human Rights of Bad Guys (Cambridge University Press, 2014), p. 250. See also the partly concurring and partly dissenting opinion by Judge Pinto de Albuqueque in Varvara v Italy, App no 17475/09 (ECtHR, 29 October 2013), para 8.
} 
in view of the fact the ECtHR only represents a minimum standard, the acceptance of a scheme by the court should not necessarily mean that the scheme is acceptable.

It is probably not controversial that in cases which do not concern the core of criminal law the protection of the criminal proceedings may not necessarily apply with their full stringency. However, the degree to which the protection of fundamental rights in confiscation proceedings outside the realm of criminal law can be diluted is not self-evident. ${ }^{96}$ Arguably neither of the aspects addressed above should be taken lightly. They all point at the importance of having sufficient safeguards in place, which are capable not only of reducing the risk of wrongful confiscation decisions, but also of ensuring that equity is taken into account when assessing the magnitude of the order where this is reasonable.

Rather than being based on, for example, any allegedly clear-cut civil - criminal divide, the necessary safeguard regime, procedural and substantive, should perhaps be tailored based on the nature of the allegation in question, the interests involved and the onerous effects on the individual of these forms of broad confiscation measures. The safeguard regime would then be based on a functional approach, which acknowledges that the factual effects on the respondent as well as the strength of the 'contextual assumption' of the property's representing illicit assets may require a safeguard regime of a certain stringen$\mathrm{cy}^{97}$ Beside the general safeguards of a right to a hearing, to legal representation, and to get a reasoned decision within a reasonable time (under Art. 6), important safeguards in this field relate to the standard of proof, the availability of bona fide protections (particularly in relation to third parties), the existence of proportionality assessments and fairness clauses, but also the possible application of the presumption of innocence. The scope, or target area, of the regime, for example, if it targets every citizen or merely a certain limited group, will be of relevance. What is important is to strike a reasonable balance between efficiency and the rights of the individual.

\section{Postludium}

The overarching challenge in confiscation law is how to create a regime which is effective, but at the same time respects the rights of the individual. It is clear that confiscation proceedings may be linked to both practical and evidential difficulties, particularly in connection with more sophisticated offences. Such difficulties may originate in lack of evidence and the defendants' unwillingness to cooperate. On the other hand, the wide confiscation regimes available today represent a very potent crime control resource that potentially facilitate the confiscation of considerable assets, following more or less substantiated allegations of criminal origin, in proceedings where traditional safeguards of criminal proceedings aimed at protecting defendants have been diluted.

The discussion in this field often demonstrates a clear divide, and tension, for example between the views of law enforcement officers and those of the academics. While the former tends to stress the need for efficacy, the latter often focus on individual rights. This tension may sometimes have as a result that an important exchange of views is inhibited. It is, however, important that we listen to, recognise and respect one another's positions in order to be able to find a balanced response to the problem.

\footnotetext{
${ }^{96}$ Simonato 2017, s. 373.

${ }^{97}$ See Boucht 2017, p. 133-139.
} 
In this field of law, therefore, it is of great importance not only to acknowledge the moral imperative that no one should benefit from his crime and of the need, therefore, to have effective confiscation regimes in place, but also to acknowledge the need to protect the fundamental rights of the individual. The statement from Germany in relation to the proposed regulation on the mutual recognition of confiscation orders in the EU captures this aptly:

'Guaranteeing cross-border asset recovery as comprehensively as possible is consistent with the principle of mutual trust. However, cooperation reaches its limits when, in altogether exceptional cases, fundamental rights are no longer safeguarded. ${ }^{98}$

${ }^{98}$ 2016/0412 (COD), 8.12.2017, p. 2. 